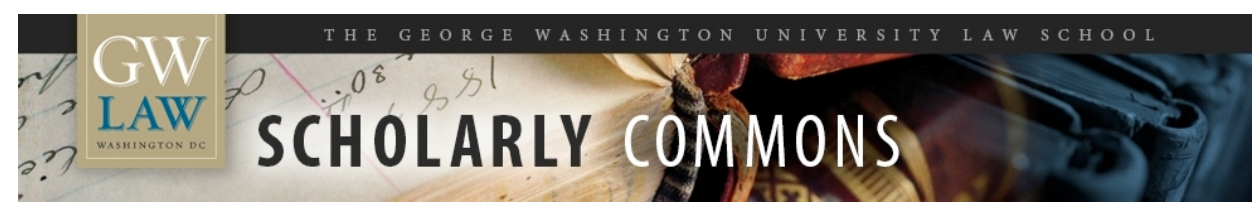

GW Law Faculty Publications \& Other Works

Faculty Scholarship

1994

\title{
GENDER EQUALITY: STATES AS LABORATORIES
}

Dawn C. Nunziato

George Washington University Law School, dnunziato@law.gwu.edu

Follow this and additional works at: https://scholarship.law.gwu.edu/faculty_publications

Part of the Law Commons

\section{Recommended Citation}

80 Virginia Law Review 945-977 (1994); GWU Law School Public Law Research Paper No. 2020-46; GWU Legal Studies Research Paper No. 2020-46.

This Article is brought to you for free and open access by the Faculty Scholarship at Scholarly Commons. It has been accepted for inclusion in GW Law Faculty Publications \& Other Works by an authorized administrator of Scholarly Commons. For more information, please contact spagel@law.gwu.edu. 


\title{
GENDER EQUALITY: STATES AS LABORATORIES ${ }^{a}$
}

\author{
Dawn C. Nunziato \\ 80 Virginia Law Review 945 (1994)
}

\section{Introduction}

Two decades ago, the calls of women's groups for gender equality captured the attention of the legislatures, the courts, and the academy. "Liberal" feminist theorists called for the passage of the federal Equal Rights Amendment ("ERA") and advocated the Supreme Court's application of heightened scrutiny to gender classifications. Meanwhile, "radical" feminist theorists claimed that the liberal approach would achieve mere formal equality or equality of treatment between men and women but would not establish women's actual equality in society. These radical theorists called for more extensive, affirmative government measures to achieve substantive equality for women.

The states' failure to ratify the liberal-supported federal ERA and the Court's failure to adopt a strict scrutiny standard for gender-classificatory laws ${ }^{1}$ may appear to have rendered this liberal-radical debate academic. With the adoption of state equal rights amendments by several states, however, this debate merely has shifted to different forums. Although state courts have interpreted their state ERAs largely in accordance with the liberal analysis, the case law from these states provides material from which to analyze the efficacy of both the liberal approach to gender equality and the radical theorists' critique of that approach. States with ERAs, therefore, serve as laboratories in which to consider the larger issue concerning which approach is more promising for achieving women's equality.

Part I of this Note briefly surveys different theoretical approaches to equality in general, exploring the contours of symmetrical and asymmetrical theories of equality. Part II focuses on gender equality theory in particular and considers liberal feminists' call for equality of treatment as well as radical feminists' demand for equality of results. Part III examines state courts' interpretations of their state ERAs -- in particular, in areas where the applications of radical and liberal feminism support different results -- in order to assess the efficacy of these theories in practice. Part IV draws some lessons from states' experiments with equality and concludes that while the liberals' call for gender-neutral legislation should be heeded in general, the radical approach offers important insights into how legislation and doctrine can be crafted to achieve formal and substantive equality for women.

\section{Defining "Equality"}

The Fourteenth Amendment to the United States Constitution guarantees "equal protection of the laws," commentators disagree on how to interpret and apply this mandate of equality. Broadly speaking, two competing mediating principles for interpreting the Equal Protection Clause have been advanced: the symmetrical antidiscrimination principle and the asymmetrical disadvantaged-group principle.

The antidiscrimination mediating principle is one of negative restraint that forbids the government from arbitrarily discriminating against classes of individuals. This principle prohibits legislative classifications based on illegitimate criteria, such as gender or race. The antidiscrimination principle is derived from the premise that equal protection requires equal treatment, which in turn requires that similarly situated parties are treated similarly. This mediating principle for interpreting the Equal Protection Clause theoretically does not provide for affirmative government action to achieve equality, but merely serves as a negative restraint on illegitimate government classifications.

Equality theorists have criticized the antidiscrimination principle for its failure to recognize that the core problems of inequality are faced by distinct disadvantaged groups, such as women and blacks, and for its inability to remedy or improve the status of these subordinated groups in society. ${ }^{3}$ Professor Owen Fiss, an early critic of the antidiscrimination principle, offers in its place an asymmetrical mediating principle, the disadvantaged-group principle, for interpreting the Equal Protection Clause. ${ }^{4}$

Professor Fiss argues that the proper concern of equal protection is with laws and practices that hurt disadvantaged groups in particular and that aggravate and perpetuate the subordinated position of such groups. ${ }^{5}$ His disadvantaged-group principle 
identifies social groups requiring special protection (including women and blacks), and calls for deferential judicial scrutiny (in practice, allowance) of policies benefiting disadvantaged groups and heightened scrutiny (disallowance) of policies impairing the status of such groups. ${ }^{6}$ Thus, the disadvantaged-group principle provides for an asymmetrical standard of scrutiny of legislation, with the level of scrutiny dependent upon whether disadvantaged groups are harmed or benefited by the legislation at issue, whereas the antidiscrimination principle provides for a symmetrical standard of scrutiny regardless of whether the legislative classification harms or benefits a disadvantaged group.

For the past century, the Supreme Court has struggled with the issue of how to interpret the Equal Protection Clause. In his oftquoted dissent in Plessy v. Ferguson, ${ }^{7}$ Justice John Marshall Harlan ostensibly adopted a symmetrical antidiscrimination principle, stating that "our Constitution is color-blind, and neither knows nor tolerates classes among citizens." ${ }^{\text {" On the other }}$ hand, the famous language of Carolene Products ${ }^{9}$ footnote four arguably endorsed an asymmetrical disadvantaged-group principle, suggesting that heightened scrutiny should be applied in cases of prejudice against "discrete and insular minorities," 10 rather than in all cases involving suspect classifications. The Court, however, rejected such an asymmetrical interpretation in Regents of the University of California v. Bakke, ${ }^{11}$ stating that "the guarantee of equal protection cannot mean one thing when applied to one individual and something else when applied to a person of another color." 12

The Court also appears to have rejected an asymmetrical disadvantaged-group principle with respect to gender discrimination. In Craig v. Boren, ${ }^{13}$ for example, the Court applied heightened scrutiny to a gender-based statute that facially disadvantaged men. ${ }^{14}$ Similarly, in Mississippi University for Women v. Hogan, ${ }^{15}$ the Court noted, "That this statutory policy discriminates against males rather than against females does not exempt it from scrutiny or reduce the standard of review." 16 In accordance with the antidiscrimination principle, the Court appears formally to apply the same level of scrutiny for "benign" gender classifications as for patently invidious ones. ${ }^{17}$

Tensions still exist among the Justices, however, regarding the proper principle for interpreting equal protection in the area of gender. Chief Justice William Rehnquist, for example, has argued repeatedly that heightened judicial scrutiny should apply only to laws which discriminate against members of the disadvantaged group (i.e., against women) rather than to all laws that classify by gender. ${ }^{18}$ The proper selection of an interpretive principle, therefore, is an important and unsettled issue in equal protection theory, especially in the area of gender equality.

\section{Theories of Gender Equality}

In recent years, the issue surrounding the proper interpretation of the equal protection mandate has been joined by theorists of gender equality. In general, liberal feminist theorists have adopted a symmetrical antidiscrimination theory of gender equality and have emphasized equality of treatment; radical feminists have advocated an asymmetrical approach and focused on equality of results for women.

Much has been written about liberal feminist theory, radical feminist theory, and the general differences between the two. ${ }^{19}$ Essentially, liberal feminism calls for equal treatment of men and women, or formal equality, and focuses on the fairness of the means of legislation; radical feminism focuses on equality of results, or substantive equality, which demands special treatment of women where necessary to attain this goal. Liberal feminists, in accord with the antidiscrimination principle, call for gender neutrality in legislation; radical feminists claim that in order to rectify the inferior position in which former discrimination has placed women, lawmakers and judges must take gender into account. Radical feminists believe that their liberal counterparts' call for equal treatment of the sexes would be efficacious only in an ideal world, and that their own approach attempts to bring about justice for women given a less than ideal world by addressing the fact that women are in an inferior starting position to men. ${ }^{20}$

In theory, liberal feminists oppose forward-looking (nonremedial) special treatment for women. Radical feminists, on the other hand, consider special treatment acceptable and necessary in some instances. Whereas liberal feminism calls for a symmetrical principle of equal protection, radical feminists sanction an asymmetrical principle to apply deferential scrutiny to genderclassificatory legislation that benefits women and stricter scrutiny to legislation that facially and concretely discriminates against women.

\section{A. Liberal Feminism's Interpretation of the ERA: The Call for Equal Treatment}


In line with their basic position on equality theory, liberal feminists interpret the federal ERA ${ }^{21}$ as a broad prohibition on legislative gender classifications. Barbara Brown, Thomas Emerson, Gail Falk, and Ann Freedman ("the Yale ERA commentators"), who most notably present the liberal feminist interpretation of the federal ERA, argue that in order to eliminate women's historically inferior social position, courts should go beyond strict scrutiny and construe the ERA to prohibit gender classifications in the law. ${ }^{22}$

Although they conclude that gender-based classifications generally should be barred, the Yale ERA commentators assert that the ERA would permit classifications based on a physical characteristic unique to one sex, such as pregnancy. ${ }^{23}$ The authors emphasize, however, that this exception would not extend to purported psychological, social, or other such asserted differences between the sexes. ${ }^{24}$ The authors argue that because this exception is susceptible of being used as a subterfuge for discrimination, ${ }^{25}$ classifications based on unique physical characteristics must bear a "close, direct and narrow relationship" to the asserted state purpose. ${ }^{26}$

The liberal approach to gender discrimination, in particular as applied to the interpretation of the federal Equal Rights Amendment, has influenced state courts in their interpretation of state ERAs. ${ }^{27}$ But this approach is not without its critics. Radical theorists have argued that the liberal approach will not effectively bring about women's substantive equality. The next Section considers the relevant aspects of the radical feminists' critique.

\section{B. The Radical Feminists' Challenge: Demanding Equality of Results}

In challenging the liberal feminist approach, Catharine MacKinnon, a leading radical feminist, extends Professor Fiss' analysis of equal protection doctrine ${ }^{28}$ to the area of gender equality. Building upon Professor Fiss' disadvantaged-group analysis, Professor MacKinnon develops an asymmetrical model of "substantive" gender equality, ${ }^{29}$ which emphasizes equality of results rather than equality or similarity of treatment. ${ }^{30}$

MacKinnon condemns the uncritical acceptance by the courts and by liberal feminists of a "masculine" notion of equality embodied in the antidiscrimination principle's "similarly situated" requirement. ${ }^{11}$ MacKinnon contends that the similarly situated requirement limits gender equality to "those issues men recognize as equality issues because they arise in contexts in which men now know they sometimes treat other men arbitrarily and irrationally." 32 MacKinnon claims that by reducing the real problem faced by women -- their subordination to men in all elements of society -- to the tidy issue of classification by gender in legislation, the liberal antidiscrimination approach "leaves out the social institutionalization of practices through which women are violated, abused, exploited, and patronized by men socially . . .." 33 According to MacKinnon, while the problems of women in society include their subordination and exploitation economically, socially, and sexually, liberal feminism's response to these problems -- calling for scrutiny of legislative gender classifications -- merely addresses future legislatively imposed harms and thus falls woefully short of achieving substantive equality. ${ }^{34}$

MacKinnon proposes an alternative model for securing gender equality whereby courts would strike down policies or practices that contribute to the maintenance of women's subordinated position, regardless of whether such laws classify on the basis of gender. ${ }^{35}$ This "subordination model" ${ }^{36}$ would explicitly acknowledge the subjugated position of women in society and would work to abolish subordinating social practices that may not be readily cognizable under the liberal feminist analysis. ${ }^{37}$

In sum, MacKinnon argues that the real barriers to women's substantive equality will not be remedied adequately by the liberal feminists' call for prohibiting legislative classifications by gender; rather, the symmetrical antidiscrimination principle advocated by liberal feminists may result in perpetuating women's subordinated position in society. In lieu of the liberal approach, MacKinnon offers her subordination model for assessing the legality of laws and practices that implicate gender equality.

While the radical-liberal debate is interesting on an academic level, it is not limited to the realm of theory. In evaluating liberal and radical theories of gender equality, feminist theorists may find it useful to observe such theories in action. As discussed in the next Section, state courts' interpretations of their state ERAs provide such an opportunity to apply and evaluate the different theories of gender equality.

\section{States' Experiments with Gender Discrimination}


In the 1970s, several states began experimenting with different models for protecting their citizens against gender discrimination. Between 1971 and 1974, fourteen states adopted equal rights amendments in some form. ${ }^{38}$ In interpreting their ERAs, these states have served as laboratories for testing and evaluating theories of gender equality. ${ }^{39}$

The interpretation of ERAs in these states has brought about changes in gender-based statutes in many areas of the law. In order to evaluate the relative merits of competing feminist theories, it is useful to focus on those areas in which liberal and radical theories compel different results. Such controversial subject areas of application include domestic relations, criminal law, insurance, and school athletics.

\section{A. Domestic Relations}

In the domestic relations arena, state courts have utilized state ERAs to strike down many types of gender classifications, with some of the major developments occurring in child custody matters. States have rejected statutory presumptions that mothers are the more fit custodians $\mathrm{s}^{40}$ and that fathers have the primary child support obligation ${ }^{41}$ and have required gender-neutral duties of child support for children born out of wedlock. ${ }^{42}$ Additionally, fathers of children born outside of marriage have gained the right, previously held only by mothers, to withhold consent from their child's adoption. ${ }^{43}$

State courts also have invalidated many gender-based classifications in the areas of marriage and divorce. For example, the Illinois Supreme Court, applying strict scrutiny, invalidated a statutory scheme that required men to be twenty-one to marry without parental consent while allowing women to marry at eighteen without consent, finding no compelling purpose to justify this difference in treatment. ${ }^{44}$ Years before the United States Supreme Court struck down laws restricting alimony obligations to husbands, ${ }^{45}$ the Pennsylvania Supreme Court invalidated separation and divorce remedies provided only to wives ${ }^{46}$ This court also held that the Pennsylvania ERA prohibits statutes that presume either the husband's ownership of household property ${ }^{47}$ or his dominance in the marriage with respect to the negotiation of prenuptial and separation agreements. ${ }^{48}$ Likewise, this court invalidated a statute that failed to recognize the nonmonetary contribution of homemakers to marital property. ${ }^{49}$

Courts in ERA states also have abolished or gender-neutralized several traditionally gender-specific common-law actions in the domestic relations field. These courts have invalidated common-law criminal conversation actions that allowed only husbands to sue their spouse's sexual partner for damages, ${ }^{50}$ extended to wives the right to recover damages for loss of their husbands' consortium, ${ }^{51}$ and mandated gender-neutral duties of spousal support during marriage. ${ }^{52}$

Despite the fears of ERA opponents, ${ }^{53}$ two areas that have remained relatively unaffected by state ERAs are restrictions on same-sex marriages and abortion. States ostensibly applying absolute bars to gender classifications have refused to grant homosexual couples the right to marry, relying upon the commonplace definition of marriage ${ }^{54}$ and claiming that their decisions entail a classification by sexual preference rather than by gender. ${ }^{55}$ States also have refused to recognize abortion rights under their ERAs, claiming that providing state funding for childbirth and not for abortion turns on a woman's decision to abort and therefore does not involve an impermissible gender classification. ${ }^{56}$

The liberal feminist interpretation offered by the Yale ERA commentators largely has guided courts in interpreting their ERAs in the domestic relations arena. ${ }^{57}$ This body of case law thus offers an opportunity to analyze the strengths and weaknesses of the liberal analysis. On the one hand, states have abolished many gender classifications that, under the guise of "protecting" women, actually served to discriminate invidiously against and to stereotype women. ${ }^{58}$ On the other hand, by requiring equal treatment of men and women in a world in which women are socially and financially subordinate to men, such state ERA cases may have served to perpetuate or worsen women's subordinated position. ${ }^{59}$ In the past two decades, for example, male plaintiffs have utilized state ERAs to require women to pay more money in child support, ${ }^{60}$ to compel women to contribute more money to their husbands' expenses, ${ }^{61}$ and to prevent women from rescinding prenuptial or separation agreements that arguably were agreed to under duress. ${ }^{62}$

The prevalence of successful male plaintiffs in state domestic relations ERA actions may support radical feminists' criticism of the inefficacy of the antidiscrimination principle for achieving substantive equality for women. ${ }^{63}$ By striving to achieve women's formal equality rather than to remedy women's subordinated status, interpretations in such cases may have worsened women's position in society. ${ }^{64}$ For example, regarding the imposition of gender neutrality in custody preferences, one commentator writes,

The removal of presumptions favoring maternal custody of young children, although an important symbolic affirmation of 
gender equality, carried a substantial price. In order to avoid expensive, traumatic, and perhaps unsuccessful custody fights, many mothers traded away property and support claims....

$\ldots$

... What apparently escaped notice of courts imposing gender neutrality in this area were the inequalities in men's and women's status following divorce. ${ }^{65}$ Furthermore, the trend toward equalization of child support payments from mothers and fathers ${ }^{66}$ may have harmful and disparate effects on women, who on average make 70 cents to every dollar a man makes. ${ }^{67}$ As one commentator notes regarding mandated equality in the domestic relations arena,

Women's . . needs in this society may continue to be undervalued and ignored unless the equality rhetoric now associated with the relationship between the sexes is challenged as inappropriate for resolving situations where they stand in inherently unequal positions. ... The metaphor has symbolic content that is preserved only at significant cost to many women who must suffer equality in this one area while the rest of the society and culture continues to treat them unequally. ${ }^{68}$

The disagreement between the majority and the concurrence in the Pennsylvania Supreme Court's decision in Simeone v. Simeone ${ }^{69}$ further highlights some of the tensions between liberal and radical theory as applied in the domestic relations arena. Declaring the presumption of male dominance in the negotiation of prenuptial agreements unconstitutional, the majority rejected the validity of the implied presumption that women are "uninformed, uneducated, and readily subjected to unfair advantage in marital agreements." 70 The court stated that "paternalistic presumptions and protections that arose to shelter women from the inferiorities and incapacities which they were perceived as having in earlier times have, appropriately, been discarded." ${ }^{\prime 1}$

The concurrence, however, criticized the majority's opinion for its erroneous assumption that, upon the passage of the state ERA, "all vestiges of inequality between the sexes have been erased," "2 and claimed that the author of the majority opinion "does not live in the real world." "ᄁ3 The concurrence asserted that the majority opinion makes "unnecessary and unwarranted declarations regarding the "equality' of women" after the passage of the ERA, declarations which, on their face, "smack of male chauvinism, an attitude that 'you women asked for it, now live with it.' "' 74

The majority and concurring opinions in this case reflect the tensions between the liberal and radical feminist positions. While the majority focuses on eradicating gender classifications embodied in laws, the concurrence emphasizes the fact that women in general and the plaintiff in particular are not in a substantially equal position to men with respect to prenuptial agreement negotiations. The concurrence joins radical feminists in asserting that treating women equally before the law -- and thus ignoring their subordinated position -- may be insufficient to secure women's actual equality in society. The majority aims for "justice in an ideal world" 75 in which women are equal in bargaining power to men, and consequently mandates the equal treatment of male and female participants to the contract negotiation. The concurrence, however, argues for the recognition of the relevant features of our less than ideal world and emphasizes that the law should intervene to "protect the subservient party" in order to secure substantive equality, and not just equality of treatment, for the female litigant. ${ }^{76}$

Thus, although ERA-mandated gender neutrality in the domestic relations arena successfully has eradicated legal countenance of sex-based stereotyping, it may have failed to address or remedy the reality of deeper sex-based disadvantages. The trend toward formally abolishing gender classifications in state domestic relations cases has not had a unilaterally positive effect toward achieving substantive equality for women. Perhaps by striving for equality in an ideal world, judges applying liberal feminist conceptions in interpreting ERAs in this area have ignored those relevant features of our imperfect world that stand in the way of women's substantive equality.

\section{B. Criminal Law}

State plaintiffs have successfully invoked state ERAs to strike down certain types of gender-specific criminal laws, whereas other types have withstood constitutional attack. For example, courts have consistently invalidated gender distinctions in the area of criminal procedure. Applying their state ERAs, courts have prohibited the use of gender-based peremptory challenges, which deny the equal rights of female venirepersons. ${ }^{77}$ The Illinois Supreme Court, applying strict scrutiny, invalidated a gender-discriminatory statute that treated seventeen-year-old male criminal defendants as adults while treating females of the same age as juveniles, finding no compelling state interest for the distinction. ${ }^{78}$ 
Gender-based criminal statutes involving sexual crimes, however, have been more resistant to state constitutional challenge. States have upheld incest statutes ${ }^{79}$ and sexual imposition statutes ${ }^{80}$ providing greater penalties for male than female offenders. State courts applying strict scrutiny,$^{81}$ as well as those ostensibly imposing absolute bars to gender classifications,$^{82}$ have upheld gender-based rape statutes by applying exceedingly deferential scrutiny to the legislation at issue. In ERA-based challenges to gender-specific statutory rape provisions, one state court has upheld differential treatment of male and female participants by referencing the unique physical characteristics exception to the mandate of gender neutrality articulated by the Yale ERA commentators. ${ }^{83}$ Several states, however, have read gender-neutral language into their gender-specific statutes governing sex crimes in order to insulate the statutes from ERA-based attack. ${ }^{84}$

Courts' divergent treatment of legislative gender classifications in cases involving sexual crimes reflects the disparate views of liberal and radical gender theorists on this issue. While liberal feminists ${ }^{85}$ (and Supreme Court Justices supportive of liberal feminism) ${ }^{86}$ would abolish gender classifications in this area, radical theorists like MacKinnon condemn such action. Facial gender neutralization in this area, according to MacKinnon, forestalls the requisite legal recognition of such "distinctive abuses of women as a gender." ${ }^{{ }^{87}}$ For example, MacKinnon criticizes the dissenting opinion in Michael M. for advocating gender neutralization of the statutory rape law at issue:

The dissent revealed more concern with avoiding the stereotyping attendant to the ideological message the law communicated than with changing the facts that make the stereotype largely true. In the interest of opposing facial distinctions and debunking the supposed myth of male sexual aggression, the fact that it is overwhelmingly girls who are sexually victimized by older males ... was completely obscured. The facts of social inequality ... that could have supported particular legislative attention to the sexual assault of girls were not even considered. ${ }^{88}$

Judges in several strict scrutiny states appear to be consistent with MacKinnon's asymmetrical approach in applying a more deferential standard of review to uphold gender-classificatory laws that disadvantage only male offenders in sexual crimes. ${ }^{89}$ Because the definition of sexual crimes is often closely related to unique physical differences between males and females, state courts have relied upon this exception to uphold gender classifications in such statutes. ${ }^{90} \mathrm{In}$ sum, the treatment of cases involving sexual crimes largely suggests a rejection in practice of the liberal feminists' call for gender-neutral legislation and an adoption of an approach closer to the radical feminists', which recognizes the reality in our imperfect world of females' sexual victimization by males.

\section{Insurance}

State ERA litigation has also challenged the permissibility of gender-based insurance rates and insurance coverage. Applying the state ERA, a Pennsylvania court struck down an insurance statute authorizing differential automobile insurance rates based on gender (while prohibiting differential rates based on race, religion, or national origin). ${ }^{91}$ The court found that even though gender-differentiated rates were based on sound actuarial principles, the rates were impermissible because they relied on and perpetuated invidious stereotypes. ${ }^{92}$ To allow such rates, the court concluded, would be contrary to the state ERA's goal of "eliminating sex as a basis for distinction." ${ }^{93}$ In subsequent litigation, the Pennsylvania National Organization for Women claimed that newly established unisex rates were unfair to women because the rates required female drivers in effect to "subsidize" male drivers. The court, however, rejected this challenge and held that these unisex rates did not violate the state ERA. ${ }^{94}$

Because liberal feminists generally advocate gender neutrality in legislation, one could reasonably assume that they would support the abolition of gender classifications in insurance rates and regulations -- even if this abolition would entail higher rates for women. ${ }^{95}$ However, the National Organization for Women ("NOW"), typically considered a liberal feminist organization, ${ }^{96}$ has opposed unisex rates because of their directly detrimental effect on women. ${ }^{97}$ MacKinnon, representing the radical feminist position, favors the stance of the Pennsylvania NOW on this issue, claiming that gender-neutral rates are less desirable than gender-specific rates because the former require women to pay for auto insurance "at the rate at which men need it." $" 98$

Liberal and radical feminist theorists, therefore, appear to agree that the unisex insurance rates mandated by state ERAs, although gender neutral, are undesirable because they are disadvantageous to women. This position for the liberal feminists, however, seems to be inconsistent. It could be argued that the liberal feminists, in advocating gender neutrality in legislation, must take the bitter with the sweet. Liberal feminists generally contend that empirical generalizations, even if accurate, cannot be utilized to support gender classifications in legislation. For example, the Yale ERA commentators argue that average 
differences between men and women -- statistically measurable differences between the sexes considered as groups, such as the fact that men are generally stronger, more athletic, or better educated -- must not be allowed to justify gender-based classifications. ${ }^{99}$ Similarly, Justice Brennan, who adopted the liberal feminist approach in Craig v. Boren, ${ }^{100}$ rejected statistically measured generalities about the sexes as a justification for the gender-differentiated alcohol consumption law at issue in the case. ${ }^{101}$ Thus, while MacKinnon's subordination test for gender-classificatory legislation is consistent in its support of genderdifferentiated insurance rates -- which do not contribute to the maintenance of women's subordinated position -- it is difficult for the liberal feminist to defend such a result. If liberal feminists feel strongly about the desirability of gender-differentiated insurance rates, this contention would militate against their position of strict legislative gender neutrality.

Another important area involving gender classifications in insurance law is health insurance coverage of pregnancy. The passage of the Pregnancy Discrimination Act ${ }^{102}$ which defined pregnancy discrimination as sex discrimination actionable under Title VII, rendered moot state efforts to make this same move under state ERAs. It is sufficient to note briefly that state plaintiffs have utilized ERAs to buttress their challenge to health insurance policies that exclude coverage of pregnancy-related costs. In Colorado, for example, a female litigant challenged her employer's group health insurance policy, which excluded normal pregnancy expenses, by relying in part on the state ERA. ${ }^{103}$ The court in that case held that the employer had violated the state ERA by providing insurance that excluded from coverage medical expenses associated with normal pregnancy, ${ }^{104}$ noting that

an employer offers fewer benefits to female employees on the basis of sex when it fails to provide them insurance coverage for pregnancy while providing male employees comprehensive coverage for all conditions, including those conditions unique to men. This disparity in the provision of comprehensive insurance benefits as a part of employment compensation constitutes discriminatory conduct on the basis of sex. ${ }^{105}$

The debate among feminists on the issue of pregnancy discrimination is too wide-ranging and complex to be addressed adequately herein. It will suffice to observe briefly that liberal feminists in general (and the Pregnancy Discrimination Act) assimilate pregnancy-related disabilities with other types of disabilities. ${ }^{106}$ Radical feminists, however, criticize this move and argue that the liberal antidiscrimination principle is least well-suited to achieve equality for women in the area of pregnancy discrimination, and that special treatment of pregnancy is necessary. ${ }^{107}$

In sum, state ERAs have been utilized to strike down gender-based insurance rates even though such rates rested on statistically accurate generalizations and were financially favorable to women. State ERAs also have been used to buttress challenges to insurance policies that excluded coverage of pregnancy expenses.

\section{School Athletics}

In the arena of school athletics, the interpretation of state ERAs has served both to insulate female teams from participation by males and to open up all-male teams to female membership. ${ }^{108}$ For example, in Petrie v. Illinois High School Ass'n, ${ }^{109} \mathrm{a}$ high school denied a male student's attempt to join the school's all-female volleyball team where the school offered no opportunities for males to play volleyball. The Illinois Supreme Court upheld the gender-segregated team by focusing explicitly on equality of results -- competitive athletic opportunities for both sexes -- instead of equality of treatment. ${ }^{110}$ Because it accepted the presumption that boys generally were better athletes than girls and thus likely would take over girls' positions on the team, the majority argued that explicitly granting boys equal treatment and allowing them to join the volleyball team would diminish girls' athletic opportunities. ${ }^{111}$ According to the court, by maintaining volleyball as the all-female fall sport and football as the all-male fall sport, the school provided comparable athletic opportunities -- equality of results -- for both boys and girls. ${ }^{112}$

The Petrie dissent, however, criticized the majority's adoption of an asymmetrical disadvantaged-group principle for the purpose of protecting female athletic opportunities. The dissent stated that it could not accept the majority's application of a different standard of scrutiny for interpreting the ERA when males instead of females were facially disadvantaged by the law at issue, noting that "there can no longer be any question but that freedom from discrimination is a two-way door." ${ }_{113}$ Referring to the explicitly symmetrical principle of equal protection adopted by the Supreme Court in Bakke, the dissent quoted from Justice Lewis Powell's judgment of the Court: " 'It is far too late to argue that the guarantee of equal protection to all persons permits the recognition of special wards entitled to a degree of protection greater than that accorded others.' "'114

While applauding the result the majority strove to reach, the dissent adhered to liberal feminist theory by emphasizing equality of treatment over equality of results. The dissent argued that the means by which the majority reached its result -- the countenance of broad presumptions about the average differences in athletic skill possessed by members of the class of each 
gender -- was impermissible. ${ }^{15}$ The dissent noted that "sex-based generalizations have been discarded in many cases where there was statistical support for the presumption upon which the classifications were based," 116 and argued, quoting Craig, that "the weakness of such statistics as predictors of any one individual's behavior 'merely illustrates that proving broad sociological propositions by statistics . . . inevitably is in tension with the normative philosophy that underlies the Equal Protection Clause.'

"117 In an effort to illustrate the tension with the normative philosophy of equality inherent in the majority's approach of "protecting weaker from stronger athletes," 118 the dissent noted,

Surely, not even the majority here, nor society generally, would condone the exclusion of blacks from an all-white basketball team on the grounds that blacks generally are more skilled at the game than whites and might tend to dominate it. ... There are legally tolerable means of categorizing athletes by size, strength, and ability. To adopt sex as a proxy for more precisely defined means of leveling off competition is both illegal and irrational. ${ }^{119}$

Quoting Justice John Paul Stevens, the dissent concluded that gender equality must mean fairness to individuals, not fairness to groups in general, and therefore that the state ERA must be interpreted to preclude treatment of individuals simply as components of a gender class. ${ }^{120}$ It should be noted, however, that the dissent's rejection of an asymmetrical disadvantagedgroup principle in favor of an antidiscrimination principle compels a result that may be directly harmful to the class of females in the short term by allowing males to displace females on the school volleyball team.

In Darrin v. Gould, ${ }^{121}$ the Washington Supreme Court heard the ERA challenge of two fully qualified high school girls who were denied permission to play on the all-male high school football team because of their gender. The court recognized that the sort of disadvantaged-group rationale advanced by the Petrie majority -- the protection and fostering of girls' athletic opportunities -- " 'can obviously have no validity with respect to those sports for which only one team exists in a school and that team's membership is limited exclusively to boys." "122 The court rejected the use of statistically based generalities to justify the assumption that girls as a group are weaker or more injury prone than boys and thus could be excluded on the basis of those average differences. ${ }^{123}$ The court focused instead on equality of treatment for the individual girls in question, noting that " 'if any individual girl is too weak, injury-prone, or unskilled, she may, of course, be excluded from competition on that basis but she cannot be excluded solely because of her sex without regard to her relevant qualifications." " 124

As Petrie and Darrin illustrate, the treatment in the ERA states of gender segregation in athletics reflects the divergent analyses of feminist theorists of this issue. Focusing on equality of results instead of equality of treatment, radical feminists claim that mandating gender neutrality in athletic regulations may diminish overall women's equality in athletics. ${ }^{125}$ Liberal feminists, however, generally reject the special treatment doctrine justifying gender segregation in athletics. ${ }^{126}$ While supportive of the goal of promoting females' athletic opportunities, liberal feminists claim that this end must be achieved without the use of presumptions or classifications based on gender. Instead, gender-neutral classifications such as height, weight, or skill must be relied upon in the effort to promote meaningful athletic competition for members of both sexes. According to liberal feminists, because the use of statistically based generalizations regarding the average differences between the sexes is capable of such serious misuse, such generalizations must be barred in all instances and cannot be paraded out when convenient for women. ${ }^{127}$

In sum, ERAs have had a pronounced effect on many areas of state law. Considering courts' interpretations of their ERAs in controversial areas provides insights into the relative merits of liberal feminist and radical feminist theory, as applied. The lessons that can be drawn from state courts' experiences in applying these theories will be considered further in the next Part.

\section{Lessons from States' Experiments}

In interpreting their ERAs, state courts generally have comported with the liberal feminist approach to gender equality by abolishing or strictly scrutinizing gender classifications embodied in legislation and common-law doctrines. Radical feminists such as MacKinnon have been critical of the liberal feminists' goal of formal equality and have offered instead an explicitly substantive analysis that would directly address women's subordinated position in society. State courts' experimentation with implementing feminist theory indicates the shortcomings of both liberal and radical theory and provides insights towards synthesizing the two.

A consideration of state ERA litigation illustrates some inadequacies in the liberal feminists' call to abolish essentially all gender classifications in legislation. In the domestic relations area, liberal feminism arguably has been applied to compel women to "suffer equality" to their detriment. ${ }^{128}$ Abolishing legislative gender classifications in this area, for example, has worked to restrict women whose spouses psychologically dominated them in contract negotiation from rescinding such 
contracts, ${ }^{129}$ to mandate equalization of alimony obligations and child support, ${ }^{130}$ and to deprive women more readily of custody of their children ${ }^{131}$ thereby worsening women's status relative to the analogous gender-specific laws. The gender neutralization of statutes involving sexual crimes ${ }^{132}$ arguably serves to mask males' sexual dominance and coercive behavior and to forestall legal attention to this abuse of women "as a gender." ${ }^{133}$ In insurance regulation, gender neutralization has required women to pay higher auto insurance premiums, ${ }^{134}$ in effect, to subsidize the inferior driving habits of their male counterparts. In the arena of school athletics, males have invoked liberal feminism's call for gender neutralization to claim the right to participate on allfemale sports teams ${ }^{135}$ a result which arguably would worsen women's athletic opportunities. A survey of state ERA litigation, therefore, lends credence to the radical feminists' charge that liberal feminism serves to bring about women's formal equality but is deficient in securing their substantive equality.

Considering the problems inherent in the liberal approach, it may be argued that the radical program for women's substantive equality should be pursued instead. If, as MacKinnon contends, liberal feminism's call for abolishment of gender classifications in our imperfect world tends to freeze women in their subordinated status, an approach that explicitly recognizes and addresses women's unequal starting position would seem to be more advantageous.

MacKinnon claims that the path to women's substantive equality begins with the judicial adoption of her proposed subordination model, which requires judges to invalidate those practices and policies that contribute to the subordination of women. ${ }^{136}$ This asymmetrical approach would leave intact legislation classifying on the basis of gender as long as such legislation does not contribute to the maintenance of women's subordinated position. MacKinnon's subordination model arguably would serve to uphold much of the legislation that liberal feminism would strike down. For example, in the domestic relations arena, the subordination principle would uphold gender-specific laws requiring males to pay more in child support or alimony than females as well as laws embodying the presumption of a husband's psychological dominance in contracting with his wife. Because such laws cause concrete harms to men and are challenged by male plaintiffs, MacKinnon's asymmetrical approach calling for deferential judicial scrutiny of gender-classificatory laws harming males arguably would uphold such laws. ${ }^{137}$ Similarly, the subordination approach would validate laws punishing only males in sex crimes, including statutory rape. ${ }^{138}$ In the arena of school athletics, MacKinnon's approach arguably would preserve gender-segregated teams, or at least insulate all-female teams from challenge by male litigants.

Despite its utility in addressing laws that cause concrete harms to women, MacKinnon's subordination principle may be ineffectual in its failure to abolish laws that cause stigmatic harms to women as well as concrete harms to men. ${ }^{139}$ For example, a child custody law which embodies the presumption that the mother is the more fit custodian may cause concrete harms to men by working to deny them custody of their children, but also causes stigmatic harm to women by embodying an invidious "separate spheres" ideology, in which the childrearing function "naturally" belongs in the women's sphere. Similarly, a domestic relations law that embodies a presumption of male psychological dominance in intraspousal contracts may cause concrete harms to men -- thus provoking them to challenge its constitutionality -- but also causes stigmatic harms to women by embodying the invidious stereotype that women as a class are psychologically subordinate or inferior to men. Because MacKinnon's subordination approach arguably would apply to uphold such laws -- in contradistinction to the liberal genderneutralization approach ${ }^{140}$-- it would leave intact such embodiments of harmful gender stereotypes. Thus, MacKinnon's subordination approach would not eradicate legal recognition of stigmatic harms to women that the majority of recent genderclassificatory laws embody.

Furthermore, an asymmetrical approach, exemplified by MacKinnon's subordination principle, calls for the establishment of different standards of scrutiny for laws discriminating against men and for those discriminating against women. As a practical matter, this approach lends itself to misapplication and misuse. A court may have difficulty determining whether a genderclassificatory law harms men or women, as the Supreme Court's difficulties in this area have demonstrated. ${ }^{141}$ Worse yet, a court may use this asymmetrical standard to uphold invidious protectionist discrimination against women "which, in practical effect, puts women, not on a pedestal, but in a cage." ${ }^{142}$ A critic of MacKinnon has argued that the subordination approach makes a return to such an era of invidious protectionist discrimination "all too likely," ${ }^{143}$ noting that Muller v. Oregon, ${ }^{144}$ a protectionist Lochner ${ }^{145}$ era case restricting women's working hours on the rationale that women's primary function was to bear children, was cited approvingly by a 1974 Supreme Court case upholding remedial legislation on behalf of women. ${ }^{146}$ Thus, the dangers inherent in applying a double standard to gender-discriminatory laws militate against MacKinnon's subordination approach to gender equality. ${ }^{147}$ Furthermore, MacKinnon's subordination model is problematic in that it relies on the courts to make subjective and complex judgments as to whether laws contribute to the subordination of women. It is far easier for a judge effectively to apply the liberal analysis' virtually absolute bar to gender-classificatory laws than it is effectively to apply the MacKinnon subordination test. If judges interpreting state ERAs were required to undertake the complex subordination inquiry before striking down gender-classificatory laws, it is doubtful that many such laws would fall. 
Consideration of state ERA litigation has illustrated advantages and disadvantages of the liberal and radical feminist approaches, as presently constituted. States' experiments with gender equality also suggest a direction for synthesis of these two theoretical approaches, in what will be referred to as the "informed gender-neutral" approach.

The informed gender-neutral approach recognizes that eradication of legislative gender classifications as required by the liberal approach benefits women by abolishing the embodiments of stigmatic harms, but also harms women by its failure to take cognizance of women's unequal starting position and its lack of sensitivity to the types of disadvantages confronted by many women in our imperfect world. The informed gender-neutral approach acknowledges and incorporates the critiques offered by radical feminism, which have served to isolate those aspects of our imperfect world that bring the most harm to women. This approach utilizes radical feminist theory to help identify areas of women's subordination which serve "as a clue, as a 'logic of identification' to the location of subordinated ... groups for whom legal assistance may be helpful." ${ }^{148}$ This approach recognizes opportunities for using gender-neutral legislation truly to remedy individual women's subordinate position, to ameliorate concrete harms as well as the stigmatic harms that accompany gender-specific classifications. Given the radical feminist critique, which identifies areas in our less than ideal world in which men tend to be psychologically, financially, sexually, and athletically dominant, the informed gender-neutral approach calls for the crafting of gender-neutral legislation and doctrines to remedy these types of subordination -- regardless of the gender of the subordinated party.

Under an informed gender-neutral approach, for example, courts would consider whether either party to a prenuptial or separation agreement exercised impermissibly coercive behavior. Thus, while the gender-based presumption of a husband's psychological dominance in spousal contract negotiations would be abolished, the court would not turn a blind eye to the existence of any overreaching which may have occurred and would not force women to "suffer equality." Instead, judges would consider whether, given the particular circumstances of the case, impermissible spousal coercion occurred during contract negotiations and would grant appropriate relief to the coerced party, whether husband or wife. Similarly, under the informed gender-neutral approach, statutory rape and sexual imposition statutes would be drafted in gender-neutral language but tailored to identify the party exercising impermissibly coercive sexual behavior. Under this approach, athletic regulations would be drafted in terms of finely tuned gender-neutral classifications that foster meaningful athletic opportunities between persons of equal skill and ability regardless of their gender. By refusing to use "female" as a placeholder for "the psychologically or financially or sexually or athletically subordinate party," such informed gender-neutral legislation and judicial doctrines would serve to remedy actual problems faced by women, while not crystallizing harmful gender stereotypes nor embodying stigmatic harms to women. By addressing disparities in starting positions without making classification turn on gender, informed gender neutrality serves the goals of both formal and substantive equality.

In sum, radical feminist analysis is helpful in identifying the types of disadvantages -- sexual, psychological, economic, or physical subordination -- that historically have confronted women as a class. The critiques offered by theorists such as MacKinnon have served to identify those aspects of our imperfect world that bring the most harm to women. Feminists in state legislatures and courthouses should adopt an informed gender-neutral approach to remedy women's subordinate position in society by attending carefully to such factors and by crafting them into gender-neutral legislation and judicial doctrines that are advantageous to women. Only then can equality of treatment be coextensive with equality of results for both women and men.

\section{Appendix}

\section{State Equal Rights Amendments}

\section{Alaska}

No person is to be denied the enjoyment of any civil or political right because of race, color, creed, sex, or national origin. The legislature shall implement this section. Alaska Const. art. I, s 3 (ratified 1972).

\section{Colorado}

Equality of rights under the law shall not be denied or abridged by the state of Colorado or any of its political subdivisions on 
account of sex. Colo. Const. art. II, s 29 (ratified 1972).

\section{Connecticut}

No person shall be denied the equal protection of the law nor be subjected to segregation or discrimination in the exercise or enjoyment of his or her civil or political rights because of religion, race, color, ancestry, national origin, or sex. Conn. Const. art. I, s 20 (ratified 1974) (amended 1984).

\section{Hawaii}

Equality of rights under the law shall not be denied or abridged by the State on account of sex. The legislature shall have the power to enforce, by appropriate legislation, the provisions of this section. Haw. Const. art. I, s 3 (ratified 1972).

\section{Illinois}

The equal protection of the laws shall not be denied or abridged on account of sex by the State or its units of local government and school districts. Ill. Const. art. I, s 18 (ratified 1970).

\section{Louisiana}

No person shall be denied the equal protection of the laws. No law shall discriminate against a person because of race or religious ideas, beliefs, or affiliations. No law shall arbitrarily, capriciously, or unreasonably discriminate against a person because of birth, age, sex, culture, physical condition, or political ideas or affiliations. La. Const. art. I, s 3 (ratified 1974).

\section{Maryland}

Equality of rights under the law shall not be abridged or denied because of sex. Md. Const. art. 46 (ratified 1972).

\section{Massachusetts}

All people are born free and equal and have certain natural, essential and unalienable rights; among which may be reckoned the right of enjoying and defending their lives and liberties; that of acquiring, possessing and protecting property; in fine, that of seeking and obtaining their safety and happiness. Equality under the law shall not be denied or abridged because of sex, race, color, creed or national origin. Mass. Const. part I, art. 1 (ratified 1976).

\section{Montana}

The dignity of the human being is inviolable. No person shall be denied the equal protection of the laws. Neither the state nor any person, firm, corporation, or institution shall discriminate against any person in the exercise of his civil or political rights on account of race, color, sex, culture, social origin or condition, or political or religious ideas. Mont. Const. art. II, s 4 (ratified 1972). 


\section{New Mexico}

Equality of rights under law shall not be denied on account of the sex of any person. N.M. Const. art. II, s 18 (ratified 1972).

\section{Pennsylvania}

Equality of rights under the law shall not be denied or abridged in the Commonwealth of Pennsylvania because of the sex of the individual. Pa. Const. art. I, s 28 (ratified 1971).

\section{Texas}

Equality under the law shall not be denied or abridged because of sex, race, color, creed, or national origin. Tex. Const. art. I, s 3a (ratified 1972).

\section{Utah}

The rights of citizens of the State of Utah to vote and hold office shall not be denied or abridged on account of sex. Both male and female citizens of this State shall enjoy equally all civil, political and religious rights and privileges. Utah Const. art. IV, $\mathrm{s}$ 1 (ratified 1896).

\section{Virginia}

The right to be free from any governmental discrimination upon the basis of religious conviction, race, color, sex, or national origin shall not be abridged, except that the mere separation of the sexes shall not be considered discrimination. Va. Const. art. I, s 11 (ratified 1970).

\section{Washington}

Equality of rights and responsibility under the law shall not be denied or abridged on account of sex. Wash. Const. art. XXXI, s 1 (ratified 1972).

\section{Wyoming}

In their inherent right to life, liberty and the pursuit of happiness, all members of the human race are equal. Wyo. Const. art. I, s 2 (ratified 1889).

Since equality in the enjoyment of natural and civil rights is only made sure through political equality, the laws of this state affecting the political rights and privileges of its citizens shall be without distinction of race, color, sex, or any circumstance or condition whatsoever other than individual incompetency, or unworthiness duly ascertained by a court of competent jurisdiction. Id. s 3 .

The rights of citizens of the State of Wyoming to vote and hold office shall not be denied or abridged on account of sex. Both male and female citizens of this state shall equally enjoy all civil, political and religious rights and privileges. Id. art. VI, s 1. 


\section{Footnotes}

"It is one of the happy incidents of the federal system that a single courageous State may, if its citizens choose, serve as a laboratory; and try novel social and economic experiments without risk to the rest of the country." New State Ice Co. v. Liebmann, 285 U.S. 262, 311 (1932) (Brandeis, J., dissenting).

Three years after the Supreme Court inaugurated its special equal protection treatment of gender in Reed v. Reed, 404 U.S. 71 (1971), the Court came within one vote of declaring gender to be a suspect classification meriting the strictest judicial scrutiny. See Frontiero v. Richardson, 411 U.S. 677 (1973). Justice William Brennan's four-vote plurality opinion in Frontiero emphatically stated reasons for granting this heightened scrutiny to laws that discriminate against women. Comparing the history of treatment of women in this country with that of blacks, Justice Brennan noted that women could not vote until this century, were often the victims of invidious stereotypes, and were subject to widespread discrimination. Id. at 684-85. He noted further that gender, like race, "frequently bears no relation to ability to perform or contribute to society." Id. at 686. In contrast, Chief Justice Warren Burger and Justices Lewis Powell and Harry Blackmun, who concurred only in the result, felt that a judicial declaration that gender was a suspect class should be postponed pending the outcome of the ratification of the federal Equal Rights Amendment, which, these Justices believed, would resolve precisely this question. Id. at 692 (Powell, J., concurring).

Eventually, Justice Brennan garnered a majority of votes in support of applying an intermediate level of scrutiny to gender classifications. See Craig v. Boren, 429 U.S. 190 (1976). This intermediate standard requires that gender classifications be "substantially related" to "important governmental objectives." Id. at 197.

U.S. Const. amend. XIV, s 1.

See, e.g., Owen M. Fiss, Groups and the Equal Protection Clause, 5 Phil. \& Pub. Aff. 107 (1976); Vernon Van Dyke, Justice as Fairness: For Groups?, 69 Am. Pol. Sci. Rev. 607 (1975).

See Fiss, supra note 3, at 108, 147-56.

5

Id. at 157 .

6

See id. at 136, 160-61. Professor Fiss argues that the disadvantaged-group principle for interpreting the Equal Protection Clause would serve explicitly redistributive aims, improve the position of historically subordinated groups, and provide a coherent theoretical framework for the preferential treatment of disadvantaged groups (in contradistinction to the antidiscrimination principle). See id. at 129-36, 175.

163 U.S. 537 (1896), overruled by Brown v. Board of Educ., 347 U.S. 483 (1954).

Id. at 559 (Harlan, J., dissenting) (emphasis added).

United States v. Carolene Prod. Co., 304 U.S. 144 (1938).

See id. at 153 n. 4 . 
See, e.g., Wengler v. Druggists Mut. Ins. Co., 446 U.S. 142 (1980) (applying intermediate scrutiny to strike down law that required widower but not widow to prove actual dependence on deceased spouse's earnings to qualify for death benefits). The Court, however, disagreed about whether the law disadvantaged the widower himself or his working wife because the wife can expect fewer death benefits to be paid to her spouse than those payable to the spouses of her male co-workers. Compare id. at 147-49 (holding that the law discriminated against both males and females) with id. at 155 (Stevens, J., concurring) (arguing that the law discriminated solely against males).

See Michael M. v. Superior Court, 450 U.S. 464, 475-76 (1981) (upholding a gender-based statutory rape statute and finding "nothing to suggest that men, because of past discrimination or peculiar disadvantages, are in need of the special solicitude of the courts"); Califano v. Goldfarb, 430 U.S. 199, 225-26 (1977) (Rehnquist, J., dissenting); Craig v. Boren, 429 U.S. 190, 219-21 (1976) (Rehnquist, J., dissenting).

For discussion of the liberal feminist approach, see, e.g., David L. Kirp, Mark G. Yudof \& Marlene S. Franks, Gender Justice (1986); Ruth Bader Ginsburg, Gender and the Constitution, 44 U. Cin. L. Rev. 1, 27-40 (1975); Wendy W. Williams, The Equality Crisis: Some Reflections on Culture, Courts, and Feminism, 7 Women's Rts. L. Rep. 175, 193200 (1982) hereinafter Williams, The Equality Crisis. For discussion of the equal treatment/special treatment debate, see, e.g., Elizabeth H. Wolgast, Equality and the Rights of Women 37-55 (1980); Wendy W. Williams, Equality's Riddle: Pregnancy and the Equal Treatment/Special Treatment Debate, 13 N.Y.U. Rev. L. \& Soc. Change 325 (1985). For the radical feminist perspective, see, e.g., Catharine A. MacKinnon, Feminism Unmodified: Discourses on Life and Law (1987). writes, "There are two ways to think about justice. One is to think about justice in an ideal world .... The other is to think about nonideal justice: given where we now find ourselves, what is the better decision?” Id. at 1700.

21 The proposed federal Equal Rights Amendment stated, in relevant part:

Section 1. Equality of rights under the law shall not be denied or abridged by the United States or by any State on account of sex.

Section 2. The Congress shall have the power to enforce, by appropriate legislation, the provisions of this article. H.R.J. Res. 208, 92d Cong., 2d Sess., 86 Stat. 1523 (1972). 
The basic principle of the Equal Rights Amendment is that sex is not a permissible factor in determining the legal rights of women, or of men. This means that the treatment of any person by the law may not be based upon the circumstance that such person is of one sex or the other... Differentiation in treatment may rest upon particular characteristics or traits of the persons affected, such as strength, intelligence, and the like. But under the Equal Rights Amendment the existence of such a characteristic or trait to a greater degree in one sex does not justify classification by sex rather than by the particular characteristic or trait.... In short, sex is a prohibited classification. Id. The authors reject the notion that the ERA merely requires strict scrutiny for gender classifications because strict scrutiny allows judges impermissible discretion in determining whether an asserted state goal is compelling and whether the law is necessary to achieve that goal. See id. at 909.

Id. at 893-94. This unique physical characteristics exception, for instance, would permit laws establishing medical leave for childbearing (but not child rearing) because such a classification is based on an actual physical difference between the sexes. Id. at 894.

Id. at 893 .

See, e.g., Muller v. Oregon, 208 U.S. 412, 422 (1908) (upholding a state law limiting women's employment in factories or laundries to ten hours a day on the grounds that a woman's "physical structure and a proper discharge of her maternal functions -- having in view not merely her own health, but the well-being of the race -- justify legislation to protect her from the greed as well as the passion of man").

Brown et al., supra note 22 , at 894 . The authors argue that by requiring gender classifications to be based on actual physical characteristics that distinguish women from men (e.g., menstruation, pregnancy, and lactation), the ERA would prohibit classifications grounded in average or stereotypical differences between the sexes (average differences such as that men are taller, heavier, and stronger than women). See id. at 889-900; see also Ann E. Freedman, Sex Equality, Sex Differences, and the Supreme Court, 92 Yale L.J. 913, 922-23 (1983) (distinguishing definitional differences between men and women from average differences). For example, under this view, the ERA would serve to strike down a law allowing only women to take extensive employment leave for childrearing purposes even though, on average, more women than men take responsibility for rearing children. Instead, the legislature would be required to recast the law to allow employment leave for the parent responsible for childrearing, whether male or female. In short, even if the "fit" between a gender classification and the underlying trait were quite good, the ERA would prohibit such classification.

See infra Part III.

See supra notes 4-6 and accompanying text.

MacKinnon is one of several radical feminist theorists who concentrate on "substantive" gender equality. This Note focuses on MacKinnon's theory because it presents a sharp contrast with liberal feminist theory.

See Catharine A. MacKinnon, Reflections on Sex Equality Under Law, 100 Yale L.J. 1281 (1991).

MacKinnon writes,

As if there could be no other way of thinking about it, in gender discrimination cases the courts adopted the content of the concept of equality from Aristotle's axiom that equality meant treating likes alike and unlikes unalike, an approach embodied in the Constitution's "similarly situated" requirement .... Id. at 1286-87. MacKinnon argues that the similarly situated analysis is incapable of dealing with the most serious problems confronting women today, including male 
sexual aggression and reproductive rights. Id. at 1297. In cases such as these, the application of the antidiscrimination principle "will not find women 'similarly situated' to men," and thus will be powerless to effect any change. MacKinnon, supra note 19, at 44-45.

Catharine A. MacKinnon, Unthinking ERA Thinking, 54 U. Chi. L. Rev. 759, 766 (1987) (reviewing Jane J. Mansbridge, Why We Lost the ERA (1986)). MacKinnon writes that the similarly situated approach "precludes the distinctive abuses of women as a gender -- for example, rape, denial of reproductive control, and prostitution -- from being considered sex equality issues at all." Id.

Id. at 765 .

See MacKinnon, supra note 30, at 1286-97. Accordingly, MacKinnon also laments the shift in the proposed language of the federal ERA from an affirmative guarantee of equal rights, as is embodied in the 1923 version, to a mere negative restraint on discrimination by the government, as is embodied in the 1971 version. See MacKinnon, supra note 32, at 770. Compare S.J. Res. 21, 68th Cong., 1st Sess., 65 Cong. Rec. 150 (1923) ("Men and women shall have equal rights throughout the United States and every place subject to its jurisdiction.") and H.R.J. Res. 75, 68th Cong., 1st Sess., 65 Cong. Rec. 285 (1923) (same) with H.R.J. Res. 208, 92d Cong., 2d Sess., 86 Stat. 1523 (1972) ( "Equality of rights under the law shall not be denied or abridged by the United States or by any State on account of sex.").

See, e.g., MacKinnon, supra note 19, at 40-45.

For the purposes of this Note, MacKinnon's approach will be referred to as the "subordination model," although she refers to her approach alternatively as the "dominance approach," id. at 40, and the "inequality approach," see, e.g., Catharine A. MacKinnon, Sexual Harassment of Working Women 4 (1979).

Under MacKinnon's analysis, such subordinating social practices include sex segregation in poverty, violence against women, unequal pay, rape, sexual assault, domestic violence, prostitution, and pornography. See MacKinnon, supra note 32 , at 769 .

Presently, sixteen states have adopted ERAs of some kind. See infra Appendix for text and ratification dates of the state provisions. In 1992, the citizens of Iowa prevented their state from becoming the seventeenth by failing to ratify their proposed ERA. See Robert Reinhold, Move to Limit Terms Gathers Steam After Winning in 14 States, N.Y. Times, Nov. 5, 1992, at B8. The equal rights provisions of two states (Utah and Wyoming) were actually part of their original constitutions. Four other states (Illinois, Louisiana, Maryland, and Montana) included equal rights provisions when they revised their constitutions, so these provisions are not amendments per se. For the sake of convenience, however, this Note will refer to all of these equal rights provisions as ERAs.

It is interesting to note the wide discrepancy between the number of states that now have state ERAs (sixteen) and the number that voted to approve the federal Equal Rights Amendment (thirty-five of the necessary thirty-eight). See generally Deborah L. Rhode, Justice and Gender 63-80 (1989) (discussing the campaign for, and aftermath of, the federal Equal Rights Amendment).

Even before states adopted equal rights amendments, courts in some states diverged from the federal model by interpreting their state equal protection clauses to apply stricter scrutiny to gender classifications. See, e.g., In re Leach, 34 N.E. 641 (Ind. 1893). Before the Supreme Court accorded heightened scrutiny to gender classifications, one state declared women a suspect class and applied heightened scrutiny to strike down gender-based statutes. See Sail'er Inn v. Kirby, 485 P.2d 529, 538-43 (Cal. 1971). Of course, in order to adhere to federal equal protection requirements, state courts must not fall below the federal minimum of intermediate scrutiny for gender classifications set out in Craig v. Boren, 429 U.S. 190 (1976). For a discussion of modern Supreme Court scrutiny of gender classifications, see supra 
note 1 .

See, e.g., Lane v. Lane, 352 N.E.2d 19, 22 (Ill. App. Ct. 1976) (applying state ERA to render maternal preference in child custody unconstitutional); Commonwealth ex rel. Spriggs v. Carson, 368 A.2d 635, 639-40 (Pa. 1977) (same). But see Harper v. Harper, 229 S.E.2d 875, 877 (Va. 1976) (recognizing implicit maternal preference despite state ERA). These disparate results may stem in part from the differing levels of scrutiny used by the respective states in applying their ERAs. For example, Pennsylvania applies a near absolute bar to legislative gender classifications; Virginia, however, uses only the federal intermediate scrutiny standard.

The standards of review for gender discrimination adopted by states with ERAs fall into three categories. First, states conforming to the federal minimum level of scrutiny to gender classifications include Utah, see Estate of Scheller v. Pessetto, 783 P.2d 70, 76-77 (Utah Ct. App. 1989), and Virginia, see Archer v. Mayes, 194 S.E.2d 707, 711 (Va. 1973). Second, states applying strict scrutiny to gender classifications include Colorado, see R. McG. v. J.W., 615 P.2d 666, 671-72 (Colo. 1980); Connecticut, see Doe v. Maher, 515 A.2d 134, 161 (Conn. Super. Ct. 1986); Hawaii, see Baehr v. Levin, 852 P.2d 44, 63-67 (Haw. 1993); Illinois, see People v. Ellis, 311 N.E.2d 98, 101 (Ill. 1974); Massachusetts, see Commonwealth v. King, 372 N.E.2d 196, 206 (Mass. 1977); and Texas, see Mercer v. Board of Trustees, 538 S.W.2d 201, 206 (Tex. Civ. App. 1976). Third, states virtually barring gender classifications include Maryland, see Rand v. Rand, 374 A.2d 900, 902-05 (Md. 1977); Pennsylvania, see Henderson v. Henderson, 327 A.2d 60,62 (Pa. 1974) (per curiam); and Washington, see Darrin v. Gould, 540 P.2d 882, 885, 893 (Wash. 1975). v. Dana, 318 A.2d 324, 326 (Pa. 1974) (same); Smith v. Smith, 534 P.2d 1033, 1036 (Wash. Ct. App. 1975) (same). statute requiring support of children born out of wedlock in order to save statute from ERA-based attack).

See Adoption of Walker, 360 A.2d 603, 605-06 (Pa. 1976) (holding that statute requiring only mother's consent for adoption of child born out of wedlock violates state ERA's absolute bar to gender-based classifications). Here, the court noted that "federal constitutional law compels the same result we reach on the basis of the Pennsylvania ERA." Id. at 606 n.11 (discussing an analogous result in Stanley v. Illinois, 405 U.S. 645 (1972)).

Phelps v. Bing, 316 N.E.2d 775, 776-77 (Ill. 1974).

Orr v. Orr, 440 U.S. 268, 278-84 (1979).

See, e.g., Henderson v. Henderson, 327 A.2d 60 (Pa. 1974) (striking down provision for alimony pendente lite to wives only).

See DiFlorido v. DiFlorido, 331 A.2d 174, 179 (Pa. 1975) (striking down presumption that household goods acquired during marriage are owned by husband).

See, e.g., Simeone v. Simeone, 581 A.2d 162, 165 (Pa. 1990) (discarding paternalistic presumption of women's inferior bargaining position and status in prenuptial agreement); see also Bell v. Bell, 379 A.2d 419, 421 (Md. Ct. Spec. App. 1977) (holding that presumption of husband's dominance in marriage cannot survive adoption of ERA).

See, e.g., DiFlorido, 331 A.2d at 179 (rejecting lower court rule that awarded ownership of household items to their actual purchaser, "since to do so ... would fail to acknowledge the equally important and often substantial nonmonetary 
contributions made by either spouse"); Holmes v. Holmes, 127 Pittsburgh Legal J. 196, 197 (Pa. Ct. C.P. Fam. Div. 1978) (finding rule limiting alimony to one-third of the paying spouse's earnings regardless of need violative of "the spirit if not the letter" of the ERA).

See Kline v. Ansell, 414 A.2d 929, 933 (Md. 1980) (holding that a criminal conversation action under which only men can sue or be sued violates state ERA).

See Hopkins v. Blanco, 320 A.2d 139, 141 (Pa. 1974); Lundgren v. Whitney’s, Inc., 614 P.2d 1272, 1275 (Wash. 1980).

See McWilliams v. McWilliams, 537 A.2d 35, 36-37 (Pa. Super. Ct. 1988) (noting that the right of financial support during marriage depends not upon the sex of the petitioner but rather upon need, in view of the relative financial circumstances of the parties).

Reverend Pat Robertson, the conservative televangelist, warned that Iowa's proposed, and ultimately defeated, ERA was part of a "socialist, anti-family political movement that encourages women to leave their husbands, kill their children, practice witchcraft, destroy capitalism and become lesbians." Pat Robertson Says Feminists Want to Kill Kids, Be Witches, Atlanta Const., Aug. 26, 1992, at A8. between two men who had lived together for eight years and otherwise met requirements for common-law marriage).

See Singer v. Hara, 522 P.2d 1187, 1191-97 (Wash. Ct. App. 1974) (upholding denial of marriage license to two male applicants against ERA challenge). This past year, however, the Hawaii Supreme Court, in Baehr v. Lewin, 852 P.2d 44 (Haw. 1993), held that its marriage statute limiting marriage to persons of the opposite sex facially discriminated on the basis of sex, thus implicating Hawaii's ERA. Id. at 60. The court, relying upon Loving v. Virginia, 388 U.S. 1 (1967), remanded the issue with the instruction that the burden rested on the state to overcome the presumption that the marriage statute is unconstitutional by demonstrating that it was narrowly tailored to further compelling state interests. Id. at 61-63, 68 .

See Fischer v. Department of Pub. Welfare, 502 A.2d 114, 124-26 (Pa. 1985). The court's discussion in Fischer lends credence to MacKinnon's critique of the similarly situated analysis for gender discrimination. MacKinnon argues that the similarly situated analysis is ineffectual in achieving women's equality because it does not apply -- and can afford no guarantee of fair and equal treatment -- in important circumstances where women are not similarly situated to men. See supra notes 31-34 and accompanying text. The court's analysis in Fischer exemplifies this deficiency in the similarly situated analysis. The Fischer court notes,

The decision whether or not to carry a fetus to term is so unique as to have no concomitance in the male of the species. Thus, this statute, which is solely directed to that unique facet is in no way analogous to those situations where the distinctions were "based exclusively on the circumstance of sex ...." Id. at 126 (quoting People v. Salinas, 551 P.2d 703, 706 (Colo. 1976)).

See, e.g., Rand v. Rand, 374 A.2d 900, 903 (Md. 1977) (explicitly citing the Yale ERA commentators for the proposition that sex cannot be a factor in child support decisions).

See, e.g., Bell v. Bell, 379 A.2d 419, 421 (Md. Ct. Spec. App. 1977) (invalidating the presumption that the husband is the dominant figure in marriage). 
See, e.g., Simeone v. Simeone, 581 A.2d 162, 165 (Pa. 1990) (upholding prenuptial agreement in which wife relinquished alimony pendente lite, noting that "the law has advanced to recognize the equal status of men and women in society").

See Conway v. Dana, 318 A.2d 324, 326-27 (Pa. 1974).

See McWilliams v. McWilliams, 537 A.2d 35, 36-37 (Pa. Super. Ct. 1988).

See Simeone, 581 A.2d at 165-68.

See MacKinnon, supra note 19, at 35-36 (criticizing gender neutrality in the family law realm).

See, e.g., Simeone, 581 A.2d at 165 (eliminating presumption of male dominance in negotiating prenuptial agreement). By eliminating this presumption, courts more likely will enforce prenuptial agreements negotiated under duress.

Rhode, supra note 38, at 148-49 (1989) (emphasis added).

See, e.g., Conway v. Dana, 318 A.2d 324, 326 (Pa. 1974); Rand v. Rand, 374 A.2d 900, 905 (Md. Ct. App. 1977).

See Maggie Mahar, The Truth about Women's Pay, Working Woman, Apr. 1993, at 52, 52.

Martha L. Fineman, Illusive Equality: On Weitzman's Divorce Revolution, 1986 Am. B. Found. Res. J. 781, 783 (reviewing Lenore J. Weitzman, The Divorce Revolution (1985)).

581 A.2d 162 (Pa. 1990).

Id. at 165 .

Id.

Id. at 168 (Papadakos, J., concurring).

Id. (Papadakos, J., concurring).

Id. (Papadakos, J., concurring).

This phrase appears in Radin, supra note 20, at 1700.

Simeone, 581 A.2d at 168 (Papadakos, J., concurring). 
See Tyler v. State, 623 A.2d 648, 651-53 (Md. 1993); State v. Burch, 830 P.2d 357, 363 (Wash. Ct. App. 1992).

People v. Ellis, 311 N.E.2d 98, 101-02 (Ill. 1974).

See People v. Yocum, 361 N.E.2d 1369 (Ill.), cert. denied, 431 U.S. 941 (1977).

See People v. Barger, 550 P.2d 1281 (Colo. 1976).

See, e.g., People v. Medrano, 321 N.E.2d 97, 98-99 (Ill. 1974). In upholding a rape statute applicable only to males, the court quoted State v. Kelly, 526 P.2d 720, 723 (Ariz. 1974), cert. denied, 420 U.S. 935 (1975), and State v. Ewald, 216 N.W.2d 213, 218 (Wis. 1974), both of which use the deferential "reasonableness" standard. Medrano, 321 N.E.2d at 98-99.

See Brooks v. State, 330 A.2d 670, 673 (Md. Ct. Spec. App. 1975). In upholding a rape statute applicable only to males, the court stated that " 'a legislative classification will not be set aside if any state of facts rationally justifying it is demonstrated to or perceived by the courts.' " Id. (quoting United States v. Maryland Sav.-Share Ins. Corp., 400 U.S. 4, 6 (1970)).

People v. Salinas, 551 P.2d 703, 706 (Colo. 1976). Citing the Yale ERA commentators, the court stated that Colorado's ERA "does not prohibit differential treatment among the sexes when, as here, that treatment is reasonably and genuinely based on physical characteristics unique to just one sex." Id. For a discussion of the Yale ERA commentators' analysis, see supra notes 22-26 and accompanying text.

See, e.g., Ex parte Groves, 571 S.W.2d 888, 893 (Tex. 1978) (reading gender-neutral language into statutory rape provision); Note, Rape and Other Sexual Offense Law Reform in Maryland, 1976-1977, 1977 U. Balt. L. Rev. 151 (noting that Maryland legislature adopted gender-neutral legislation in its statutes dealing with sexual crimes).

See, e.g., Williams, The Equality Crisis, supra note 19, at 181-90.

See Michael M. v. Superior Court, 450 U.S. 464, 488 (1981) (Brennan, J., dissenting).

MacKinnon, supra note 32, at 766.

MacKinnon, supra note 30, at 1305.

See supra notes 81-83 and accompanying text. For example, the court in People v. Salinas, 551 P.2d 703 (Colo. 1976), upholding a rape statute that punishes only male offenders, focused on physical characteristics unique to one sex. Id. at 706. This focus alone, however, is not enough to justify its falling within the liberal feminists' unique physical characteristics exception. See supra note 23 and accompanying text. The liberal view articulated by the Yale ERA commentators demands that the unique physical characteristic bear a "close, direct, and narrow relation" to the asserted state purpose. See supra note 26 and accompanying text. The Salinas court, however, does not undertake such an inquiry. See Salinas, 551 P.2d at 706; see also Brooks v. State, 330 A.2d 670, 673 (Md. 1975) (applying most lenient scrutiny to uphold gender-based rape law and not inquiring into state purpose). 
See Salinas, 551 P.2d at 706.

Bartholomew v. Foster, 541 A.2d 393 (Pa. Commw. Ct. 1988), aff'd, 563 A.2d 1390 (Pa. 1989).

Id. at 397.

Id. at 398 .

Pennsylvania Nat'l Org. for Women v. Commonwealth Ins. Dep't, 551 A.2d 1162, 1166-67 (Pa. Commw. Ct. 1988), appeal denied, 561 A.2d 744 (Pa. 1989).

Acting in the statutory context of Title VII, the Supreme Court, which leans toward the liberal feminist position, has refused to countenance gender-differentiated retirement plans and employee group insurance premiums based on the accurate generalization that women live longer than men. See Arizona Governing Comm. for Tax Deferred Annuity \& Deferred Compensation Plans v. Norris, 463 U.S. 1073, 1081-86 (1983) (invalidating gender differentiation in retirement benefits); Los Angeles Dep't of Water \& Power v. Manhart, 435 U.S. 702, 707-11 (1978) (invalidating gender differentiation in employee group insurance premiums).

See Zillah R. Eisenstein, The Radical Future of Liberal Feminism 193 (1986).

See text accompanying supra note 94 .

MacKinnon, supra note 32 , at 768 n. 18 .

See Brown et al., supra note 22, at 889-900.

429 U.S. 190 (1976).

Justice Brennan asserted that "statistically measured but loose-fitting generalities concerning the drinking tendencies of aggregate groups" must not be allowed to render equal protection principles inapplicable. Id. at 208-09. As an example of the dangers inherent in legislation incorporating statistically based generalities, Justice Brennan warned that "States could freely favor Jews and Italian Catholics at the expense of all other Americans in regulating alcohol consumption, since available studies regularly demonstrate that the former two groups exhibit the lowest rates of problem drinking.” Id. at 208 n. 22.

42 U.S.C. s 2000e(k) (1988).

Colorado Civil Rights Comm’n v. Traveler's Ins. Co., 759 P.2d 1358, 1360 (Colo. 1988).

Id. at 1365 .

Id. at 1363 . 
See Williams, The Equality Crisis, supra note 19, at 190-200.

See MacKinnon, supra note 30, at 1295-97.

School athletic programs must also withstand scrutiny under Title IX of the Education Amendments of 1972, which forbids discrimination based on sex in any educational program or activity receiving federal financial assistance. See 20 U.S.C. s 1681 (1988).

394 N.E.2d 855 (Ill. App. Ct. 1979).

Id. at 862 .

Id. at 864

Id. In order to reach its result, the majority deemed the "preservation, fostering and promotion of interscholastic athletic competition for both boys and girls" to be a "compelling governmental interest" and noted that although gendersegregated teams were not an "absolute necessity" for achieving this end, "the combination of problems which we believe to be likely to arise from attempts to do so through other classifications e.g., through gender-neutral classifications such as height, weight, or skill requirements, creates a substantial element of necessity.” Id. at 863.

Id. at 866 (Craven, J., dissenting).

Id. (Craven, J., dissenting) (quoting Regents of the Univ. of Cal. v. Bakke, 438 U.S. 265, 295 (1978) (opinion of Powell, J.)).

Id. at 866-67 (Craven, J., dissenting).

Id. at 867 (Craven, J., dissenting). The dissent pointed to the presumption in Reed v. Reed, 404 U.S. 71 (1971), that men were more conversant in business than women and the presumption in Frontiero v. Richardson, 411 U.S. 677 (1973), that men were more likely to be the breadwinners in the family than women as examples of impermissible sexbased generalizations similar to that adopted by the majority opinion. Petrie, 394 N.E.2d at 867 (Craven, J., dissenting).

Petrie, 394 N.E.2d at 867 (Craven, J., dissenting) (quoting Craig v. Boren, 429 U.S. 190, 204 (1976)).

Id. (Craven, J., dissenting).

Id. (Craven, J., dissenting).

Id. at 867-68 (Craven, J., dissenting) (quoting Los Angeles Dep't of Water \& Power v. Manhart, 435 U.S. 702, 707-09 (1978)). 
540 P.2d 882 (Wash. 1975).

Id. at 890 (quoting Commonwealth v. Pennsylvania Interscholastic Athletic Ass'n, 334 A.2d 839, 842 (Pa. Commw. Ct. 1975)).

Id. at 892 .

Id. at 891 (quoting Pennsylvania Interscholastic Athletic Ass'n, 334 A.2d at 843). The court considered but rejected the notion that the maintenance of gender-segregated sports teams in general was necessary to protect and foster girls' athletic programs, finding that such an end could not be considered a compelling state interest because "the overriding compelling state interest as adopted by the people of this state in 1972 is that: "Equality of rights and responsibility under the law shall not be denied or abridged on account of sex.' " Id. at 892 (quoting Wash. Const. art. XXXI, s 1).

See MacKinnon, supra note 19, at 245 n.35.

See, e.g., Brown et al., supra note 22, at 902 .

See, e.g., Williams, The Equality Crisis, supra note 19, at 187-88.

See Fineman, supra note 68, at 783; see also supra Part III.A (discussing state courts', as well as liberal and radical feminists', reaction to gender-classificatory laws in the context of domestic relations).

Simeone v. Simeone, 581 A.2d 162 (Pa. 1990).

Henderson v. Henderson, 327 A.2d 60 (Pa. 1974) (alimony obligations); Conway v. Dana, 318 A.2d 324 (Pa. 1974) (child support).

Commonwealth ex rel. Spriggs v. Carson, 368 A.2d 635 (Pa. 1977).

Ex parte Groves, 571 S.W.2d 888 (Tex. Crim. App. 1978).

See MacKinnon, supra note 30, at 1305-06.

Bartholomew v. Foster, 541 A.2d 393 (Pa. Commw. Ct. 1988), aff'd, 563 A.2d 1390 (Pa. 1989).

Petrie v. Illinois High Sch. Ass'n, 394 N.E.2d 855 (Ill. App. Ct. 1979).

See supra notes 35-37 and accompanying text.

Professor Joan Williams considers the application of MacKinnon's subordination principle to gender-based presumptions in relation to employment and family responsibilities. See Joan C. Williams, Deconstructing Gender, 87 
Mich. L. Rev. 797, 838 (1989). Professor Williams argues that "MacKinnon's approach without a doubt would serve to reinforce and to legitimize gender stereotypes that are an integral part of the increasingly oppressive gender system," such as the maternal presumption in child-custody decisions. Id.

See supra text accompanying notes 87-88.

Stigmatic harms include harms that impose a badge of inferiority -- a stigma -- upon a class of persons but which do not impose more concrete injury. The Supreme Court first referred to stigmatic harm in Strauder v. West Virginia, 100 U.S. 303 (1880). In Strauder, a black defendant was convicted of murder by a jury from which blacks were excluded by law. The Court focused not only on the concrete harm to the black defendant himself but also on the stigmatic harm the exclusionary law caused to blacks in general by barring them from serving on juries. The Court wrote,

The very fact that colored people are singled out and expressly denied by a statute all right to participate in the administration of the law, as jurors, because of their color ... is practically a brand upon them, affixed by the law, an assertion of their inferiority, and a stimulant to ... race prejudice .... Id. at 308 (emphasis added).

The liberal feminist approach, with its emphasis on equality of treatment, prohibits all classifications based on gender. Therefore, laws embodying stigmatic harms to women, as well as laws embodying concrete harms to women, would be struck down under the liberal approach. By advocating gender-neutral legislation, liberal feminist theory may take away concrete advantages to women, but it also eradicates presumptions implying women's inferior or subordinate status.

Compare Wengler v. Druggists Mut. Ins. Co., 446 U.S. 142, 147-49 (1980) (striking down law favoring widows and disfavoring widowers on grounds that law harms both widowers and working women) with Califano v. Goldfarb, 430 U.S. 199, 218 (1977) (Stevens, J., concurring) (arguing that a classification more favorable to widows than widowers does not invidiously discriminate against women).

Frontiero v. Richardson, 411 U.S. 677, 684 (1973).

Nadine Taub, Book Review, 80 Colum. L. Rev. 1686, 1691-92 (1980) (reviewing Catharine A. MacKinnon, Sexual Harassment of Working Women (1979)).

208 U.S. 412 (1908).

Lochner v. New York, 198 U.S. 45 (1905), overruled by West Coast Hotel Co. v. Parrish, 300 U.S. 379 (1937).

Kahn v. Shevin, 416 U.S. 351, 356 n.10 (1974) (upholding beneficial tax exemption for widows).

See, e.g., Williams, The Equality Crisis, supra note 19, at 189-90, 195-99 (focusing on the great costs of special treatment and arguing that special "protections" are a double-edged sword).

Mary J. Frug, Progressive Feminist Legal Scholarship: Can We Claim “A Different Voice”?, 15 Harv. Women's L.J. 37, 64 (1992). 